\title{
Taxonomic remarks on the genus Bogdocosa Ponomarev et Belosludtsev, 2008 (Aranei: Lycosidae)
}

\author{
Таксономические заметки о роде Bogdocosa \\ Ponomarev et Belosludtsev, 2008 (Aranei: Lycosidae)
}

\author{
Sergei L. Esyunin ${ }^{1}$, Aleksandr V. Ponomarev ${ }^{2}$ \\ С. $\Lambda$. Есюнин ${ }^{1}$, А.B. Пономарёв ${ }^{2}$
}

\footnotetext{
${ }^{1}$ Perm State University, Bukireva Street 15, Perm 614600 Russia. E-mail: Sergei.Esyunin@psu.ru Пермский государственный университет, ул. Букирева 15, Пермь 614600 Россия.

${ }^{2}$ Southern Scientific Centre, Russian Academy of Sciences, Chekhov str. 41, Rostov-on-Don 344006 Russia. Email: ponomarev1952@mail.ru Южный научный центр РАН, пр. Чехова, 41, Ростов-на-Дону 344006 Россия.
}

KEY WORDS: Araneae, Central Asia, new combinations, new synonym, wolf-spiders.

КЛЮЧЕВЫЕ СЛОВА: Araneae, Центральная Азия, новые комбинации, новые синоним, пауки-волки.

ABSTRACT. Bogdocosa Ponomarev et Belosludtsev, 2008 is proven to be a monotype genus of the Lycosidae. A revision of the taxonomic status of some Central Asian wolf-spider species, such as Alopecosa kronebergi Andreeva, 1976 (from Tajikistan), Bogdocosa baskuntchakensis Ponomarev et Belosludtsev, 2008 (from cis-Caspian Region and Iran) and Pardosa beijiangensis $\mathrm{Hu}$ et $\mathrm{Wu}, 1989$ of the multivaga species group (from East China), has resulted in two new synonyms and a new combination: Bogdocosa kronebergi (Andreeva, 1976) comb.n. $($ ex Alopecosa $)=P$. beijiangensis $\mathrm{Hu}$ et $\mathrm{Wu}, 1989$ syn.n. = B. baskuntchakensis Ponomarev et Belosludtsev, 2008 syn.n. It is shown that the type series of Alopecosa latifasciata (Kroneberg, 1875) is heterogeneous and contains two syntype males from Magian Vil. (Panjakent District, Sughd Region, Tajikistan) and females of $B$. kronebergi from Samarkand Town (Uzbekistan). An updated diagnosis and description of Bogdocosa genus are provided; the distribution of $B$. kronebergi is mapped.

How to cite this article: Esyunin S.L., Ponomarev A.V. 2018. Taxonomic remarks on the genus Bogdocosa Ponomarev et Belosludtsev, 2008 (Aranei: Lycosidae) // Arthropoda Selecta. Vol.27. No.1. P.61-68. doi: 10.15298/arthsel. 27.1.09

PЕЗЮМЕ. Bogdocosa Ponomarev et Belosludtsev, 2008 рассматривается как монотипичный род Lycosidae. Пересмотр таксономического статуса некоторых центрально-азиатских видов пауков-волков: Alopecosa kronebergi Andreeva, 1976 (из Таджикистана), Bogdocosa baskuntchakensis Ponomarev et Belosludtsev, 2008 (из Прикаспийского региона и Ирана) и Pardosa beijiangensis $\mathrm{Hu}$ et $\mathrm{Wu}, 1989$ из группы видов multivaga (из Западного Китая) позволил выявить новые синонимы и новые комбинации: Bogdocosa kronebergi (Andreeva, 1976) comb.n.
$($ ex. Alopecosa $)=P$. beijiangensis $\mathrm{Hu}$ et $\mathrm{Wu}, 1989$ syn.n. = B. baskuntchakensis Ponomarev et Belosludtsev, 2008 syn.n. Показано, что типовая серия вида Alopecosa latifasciata (Kroneberg, 1875) является сборной и содержит типового самца из поселка Магиан (Пенджикентский район, Согдийская область, Таджикистан) и самок B. kronebergi из окрестностей Самарканда (Узбекистан). Даны уточненный диагноз и описание рода Bogdocosa; pacпространение B. kronebergi закартировано.

\section{Introduction}

The spider genus Bogdocosa Ponomarev et Belosludtsev, 2008, with the type species B. baskuntchakensis Ponomarev et Belosludtsev, 2008, was described on the basis of both sexes from the Bogdinsko-Baskunchakskiy Reserve (Astrakhan Region, Russia). The authors [Ponomarev, Belosludtsev, 2008] compared this genus with such genera as Pardosa C.L. Koch, 1847 and Aulonia C.L. Koch, 1847. In their opinion, Bogdocosa is well distinguished from both by the apical position of the embolus. Having originally known from the south part of European Russia only, B. baskuntchakensis was later recorded from the northern part of Caspian Sea Region [Abdurakhmanov et al., 2012; Ponomarev, Abdurakhmanov, 2014] and Iran [Mirshamsi et al., 2015].

While studying two females of wolf-spiders from eastern Kazakhstan, one of us (SE) has found out that they are similar with two species of different genera: $B$. baskuntchakensis and Alopecosa kronebergi Andreeva, 1976. This observation made us to analyze all the information about both Central Asian species. As a result, some mistakes and confusion regarding the name B. baskuntchakensis have been revealed. 
First, based on the original description, the species A. kronebergi described from Tajikistan is indeed identical to the type species of Bogdocosa and thus is to be transferred to this genus, becoming its type species as a senior synonym of Bogdocosa baskuntchakensis (see below). Second, Pardosa beijiangensis $\mathrm{Hu}$ et Wu, 1989 described from Xinjiang Uyghur Autonomous Region (China) is also identical to B. kronebergi. Recently, $P$. beijiangensis was redescribed, illustrated and placed in the multivaga species group by Chen, Song [2004]; the latter taxonomic solution was, in our opinion, a mistake. Third, the two females from Samarkand (Uzbekistan) identified, described and illustrated by Kroneberg [1875] as Tarentula latifasciata Kroneberg, 1875 are undoubtedly identical to those of $B$. kronebergi in their size, body coloration and shape of the epigyne. The fact that the females from Samarkand are markedly different in their coloration from the syntype males of A. latifasciata was indicated by the original author [Kroneberg, 1875: 40], who noticed that "the difference in the size of males and females is so significant ... that the latter can be attributed to a separate species". Charitonov [1946], without considering the viewpoint of Kroneberg, illustrated the epigyne [Ibid.: fig. 20] and described [Charitonov, 1969] the female of $A$. latifasciata that did not match Kroneberg's original figure and description. Thus, the type series of $A$. latifasciata is heterogeneous, consisting of the syntype males from Magian Village (Panjakent District, Sughd Region, Tajikistan) and two females of B. kronebergi from Samarkand Town (Uzbekistan).

A re-examination of the materials of the Pardosa multivaga species group stored in the Zoological $\mathrm{Mu}-$ seum of the Moscow State University made it possible to reveal an erroneous identification.

In the present paper, we aim to provide an updated diagnosis, definition and description of Bogdocosa, to correct the aforementioned identifications, and to establish a new combination and two new synonyms.

\section{Material and methods}

The material studied here is deposited in the Zoological Museum of the Moscow State University (ZMUM, curator: K.G. Mikhailov), the department of Invertebrate Zoology and Aquatic Ecology of the Perm State University (PSU, curator: S.L. Esyunin) and Ponomarev's personal collection (PC). Photographs are made by means of the camera SONY NEX-C3 attached to MIKMED-6 optical microscope at the Southern Scientific Centre, Russian Academy of Sciences, Rostov-onDon. SEM micrographs were made by means of a Hitachi TM3000 SEM microscope with BSE (backscattered electrons) at the Perm State University, Perm.

The distribution map was produced by using the online mapping software SimpleMappr [Shorthouse, 2010] with slight modifications.

Abbreviations used in the text and figures are as follows: ALE - anterior lateral eye, AME - anterior median eye.
The terminology of the Bogdocosa palp morphology follows Marusik et al. [2011], that of the epigyne morphology Chen, Song [2004].

Genus Bogdocosa Ponomarev et Belosludtsev, 2008

TYPE SPECIES. Alopecosa kronebergi Andreeva, 1976, as a senior synonym of Bogdocosa baskuntchakensis Ponomarev et Belosludtsev, 2008 (see below).

ETYMOLOGY. The generic name consists of two parts: 'Bogdo', referring to the name of Bogdo Mt. in the northern part of cis-Caspian Region, and the second half of the generic name $L y \cos a$, which is often used to form generic names in the wolf-spiders. Gender: feminine.

DIAGNOSIS AND AFFINITIES. Bogdocosa is similar to Evippa Simon, 1882 and Xerolycosa Dahl, 1908 of the subfamily Evippinae Zyuzin, 1985 in some characters of the male palp: the cymbium with apical spines, the palea is absent, the terminal apophysis is associated with the embolus, the tegular apophysis with median prominences and branches (as in all Xerolycosa and some Evippa species), the embolus is bent before its apex. Yet, the genus differs from other Evippinae genera in the following characters: (1) the embolus does not form a flat, almost cyclic structure located at the bottom of the recess ('alveolus' sensu Zyuzin [1985]) as in the rest of Evippinae, (2) the tegular apophysis is arranged medially vs. retrolaterally in other Evippinae, (3) the epigynal septum and lateral pocket ('windows of epigyne' sensu Marusik et al. [2011]) are absent, but they present in other Evippinae genera.

A strong similarity of Bogdocosa species with those of the Pardosa multivaga species group was first noticed by Chen, Song [2004]. However, in our opinion, Bogdocosa differs from the multivaga group by (1) the thick spine-like hairs on the male sternum (Fig. 5) and (2) the bulge on the palpal tibia (Fig. 2) (both these characters are absent from the latter species group), (3) the lack of the lobe on the embolic base, which is present in the multivaga group [Chen, Song, 2004, figs 17-22, 32-35], (4) the narrow anterior half of the median epigynal plate, which is present in the females of the multivaga group [Chen, Song, 2004, figs 11, 13, 15, 30], and (5) the position of the copulatory openings, which are situated at the posterior margin of the median epigynal plate in Bogdocosa (Fig. 7), while at the anterior margin in the multivagagroup [Chen, Song, 2004, figs 12, 14, 16, 31]. Besides, we are in favour of the viewpoint by Yin et al. [1997], who stated that the two Pardosa species - P. multivaga Simon, 1880 and $P$. xinjiangensis $\mathrm{Hu}$ et $\mathrm{Wu}, 1989-$ differ from the generotype, P. alacris (C.L. Koch, 1833) by their conformation of copulatory organs; yet, in our opinion, the multivaga species group deserves a status of a separate genus that is close to Bogdocosa.

On the other hand, by their copulatory organs, Bogdocosa is similar to two predominantly African lycosid genera Pterartoria Purcell, 1903 and Trabea Simon, 1876, but differs from them in the shape of carapace and the size of median eye row [cf. Russell-Smith, 1981, 1982]. The common characters in Bogdocosa and the Pterartoria-Trabea complex are as follow: (1) the looped embolus that is situated apically in bulbus, (2) the big plate-shape tegular apophysis with two or three branches (it should be noticed that Russell-Smith [1982: 70] considers the 'tegular apophysis' of Trabea not homologous to that of other Lycosidae), (3) the tegulum with a prolateral tegular lobe, (4) the epigyne with a median plate, without septum. However, Bogdocosa 


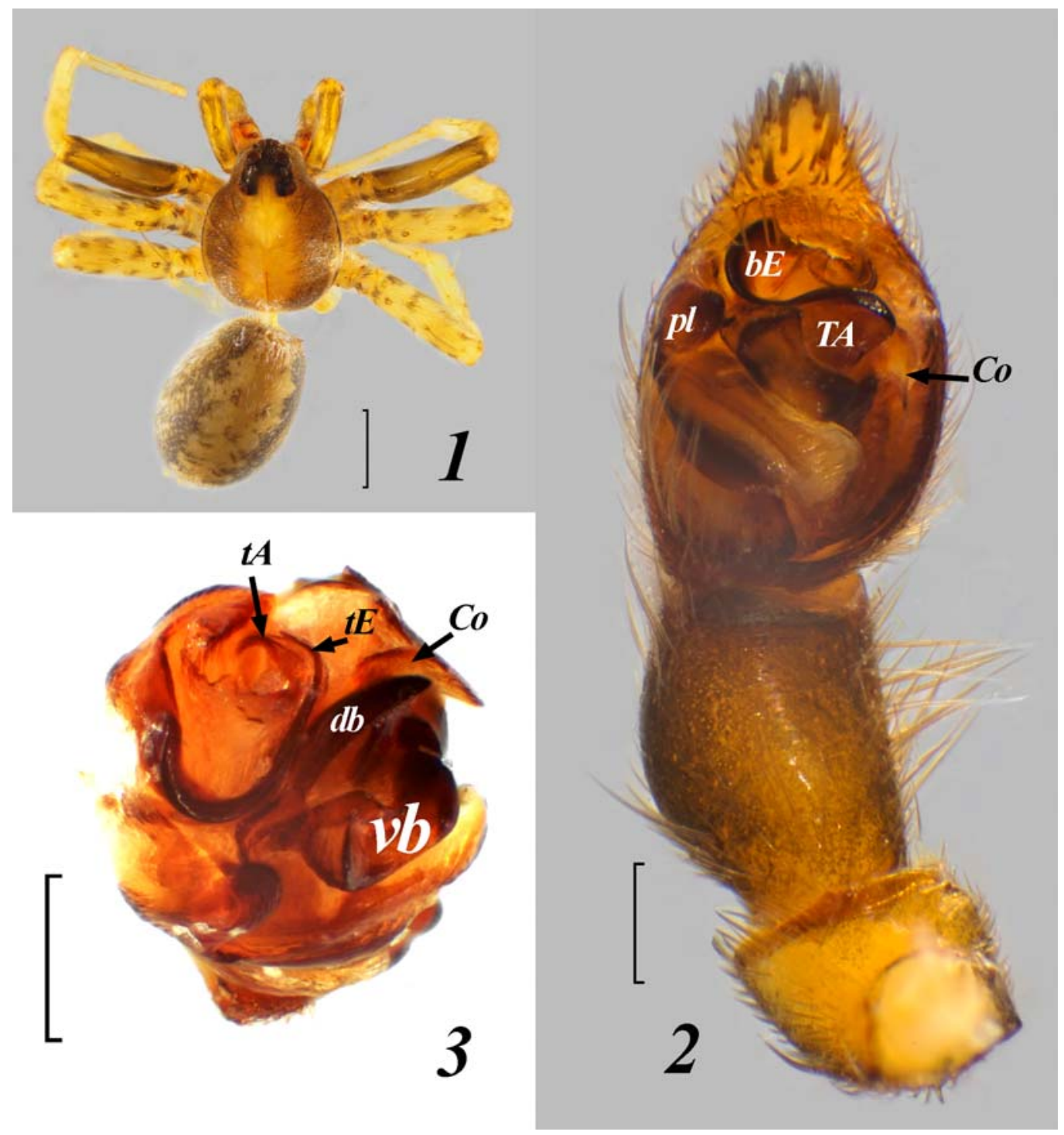

Figs 1-3. Male habitus (1, dorsal view), palpus (2, ventral view) and bulbus (3, anterior view) of Bogdocosa kronebergi (Andreeva, 1976). Scale bars: $1-1 \mathrm{~mm} ; 2,3-0.2 \mathrm{~mm}$.

Abbreviations: $b E-$ embolic base; $C o-$ conductor; $d b-$ dorsal branch of tegular apophysis; $T A-$ tegular apophysis; $t A-$ terminal apophysis; $t E$ - embolic tip; $v b$ - ventral branch of tegular apophysis.

Рис. 1-3. Тело самца (1, сверху), пальпа (2, снизу) и бульбус (3, спереди) Bogdocosa kronebergi (Andreeva, 1976). Масштаб: 1 1 мм; 2, 3-0,2 мм.

Сокращения: $b E-$ основание эмболюса; $C o-$ кондуктор; $d b-$ дорсальная ветвь тегулярного отростка; $T A-$ тегулярный отросток; $t A-$ терминальный отросток; $t E$ - вершина эмболюса; $v b-$ вентральная ветвь тегулярного отростка.

differs from Trabea in having not enlarged eyes of the median row ('markedly enlarged' in Trabea [Russell-Smith, 1982: 70]), and from both African genera in the absence of such a specific structure of the male palp as the embolic tip lying beneath a transparent membranous fold of the tegulum [see Russell-Smith, 1982: 70], as well as in the position of the copulatory openings: in Bogdocosa they are situated at the posterior margin of the median epigynal plate, whereas in Trabea and Pterartoria at the anterior margin (e.g., figs 7, 8 in Snazell [1983], figs 3G, 7E, 12F in Russell-Smith [1981]).

Having discussed the position of the two genera in the family Lycosidae, Russell-Smith [1982: 70] came to the following conclusion: "It is probable that these two genera, together with Pterartoria Purcell, 1903, should be placed in a new taxon of their". Taking into account the significant differences of Bogdocosa from other genera in the Evippinae and Lycosinae sensu Zyuzin [1985], it is safe to conclude that the position of the genus Bogdocosa within the Lycosidae is to be treated as unresolved.

DESCRIPTION. Medium size: $\sigma^{7} \sigma^{7}-4.4$ to $5.7 \mathrm{~mm}$ and OP -5.0 to $8.2 \mathrm{~mm}$ in length. Sexes are alike, with a poorly marked colour dimorphism $\left(\sigma^{\top} \sigma^{7}\right.$ darker, marginal light bands on carapace narrower, femur I dark); yet, $\sigma^{7} \sigma^{7}$ have spine-like hairs on the sternum (Fig. 5) (normal hairs in females) and darker femora I (Fig. 1). Carapace brown, with 

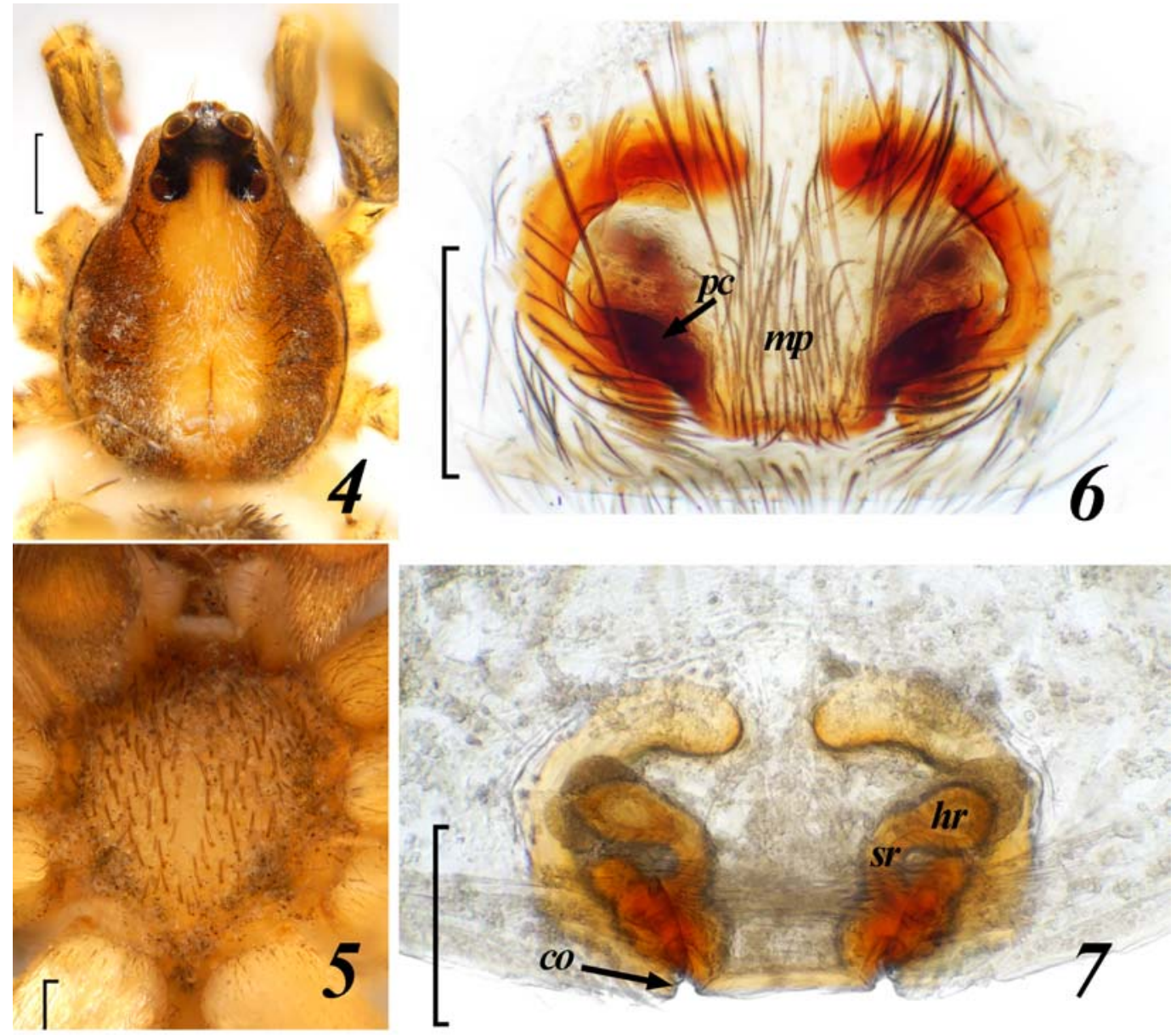

Figs 4-7. Male carapace (4, dorsal view), male sternum (5, ventral view) and epigyne (6, 7, ventral and dorsal views, respectively) of Bogdocosa kronebergi (Andreeva, 1976). Scale bars: 4, 5-0.5 mm, 6, $7-0.2 \mathrm{~mm}$.

Abbreviations: $c o$ - copulatory opinion; $h r$ - head of receptaculum; $m p-$ median epigynal plate; $s r$ - stem of receptaculum; $p c-$ pocket of median epigynal plate.

Рис. 4-7. Карапакс (4, сверху) и стернум (5, снизу) самца и эпигина (6, 7, снизу и сверху, соотвественно) Bogdocosa kronebergi (Andreeva, 1976). Масштаб: 4, 5-0,5 мм, 6, $7-0,2$ мм.

Сокращения: co - копулятивные отверстия; $h r$ - головка рецептакула; $m p-$ срединная пластинка эпигины; $s r-$ ножка рецептакула; $p c$ - складка пластинки эпигины.

a light wide median stripe and narrow marginal bands (Fig. 1). Median band extends anteriorly between eyes of the posterior row (Fig. 4). Anterior eye row straight, slightly shorter than the median one. AME larger than ALE. Chelicerae brown, with three teeth on both margins. Sternum yellow; in $\sigma^{7} \sigma^{7}$ with spine-like black hairs (Fig. 5), in 우 with long black hairs. Legs yellow, femora with annulations (Fig. 1). Abdomen grey to grayish brown, with a wide pale median stripe dorsally, and yellow to yellow-grey stripes ventrally.

Male palp (Figs 2, 3, 8-12): cymbium without a distal claw, but with several strong spines (Fig. 9); embolus situated apically on bulbus (Fig. 2), benting before its apex (Figs $3,10)$; terminal apophysis $(t A)$ associated with embolus (Figs 3, 10); tegular apophysis $(T A)$ plate-shape, with two branches: ventral $(v b)$ and dorsal $(d b)$ (Fig. 11); tegulum with a prolateral tegular lobe $(p l)$ and retrolateral conductor (Co) (Fig. 2, 12).

Female epigyne (Figs 6, 7): median plate $(\mathrm{mp})$ transverse, with a pair of pockets $(p c)$ near its posterior margin
(Fig. 6), septal stem absent; copulatory openings (co) situated near the posterior margin of epigynal plate; receptacles Cshaped, their distal parts directing anterior-laterad (Fig. 7).

COMPOSITION. Bogdocosa kronebergi (Andreeva, 1976), comb.n.

DISTRIBUTION. Central Asia (Fig. 13): from Iran and Daghestan to Xinjiang, China, north to Astrakhan Region of Russia and West-Kazakhstan Region, south to Khorasan-e Razavi Province of Iran.

Bogdocosa kronebergi (Andreeva, 1976) comb.n. Figs 1-12.

Tarentula latifasciata Kroneberg, 1875: 39, P1. 4, Fig. 27e ( + only!; mismatched).

Alopecosa kronebergi Andreeva, 1976: 45, Figs 54-55 (O'ㅇ).

Pardosa beijiangensis $\mathrm{Hu}$ et Wu, 1989: 210, Fig.174.1-5 ( $\left(\mathrm{O}^{7}+\right)$, syn.n.

Pardosa beijiangensis: Zhao, 1993: 85, Fig. 35a-c (○º; copied from $\mathrm{Hu}, \mathrm{Wu}[1989])$. 


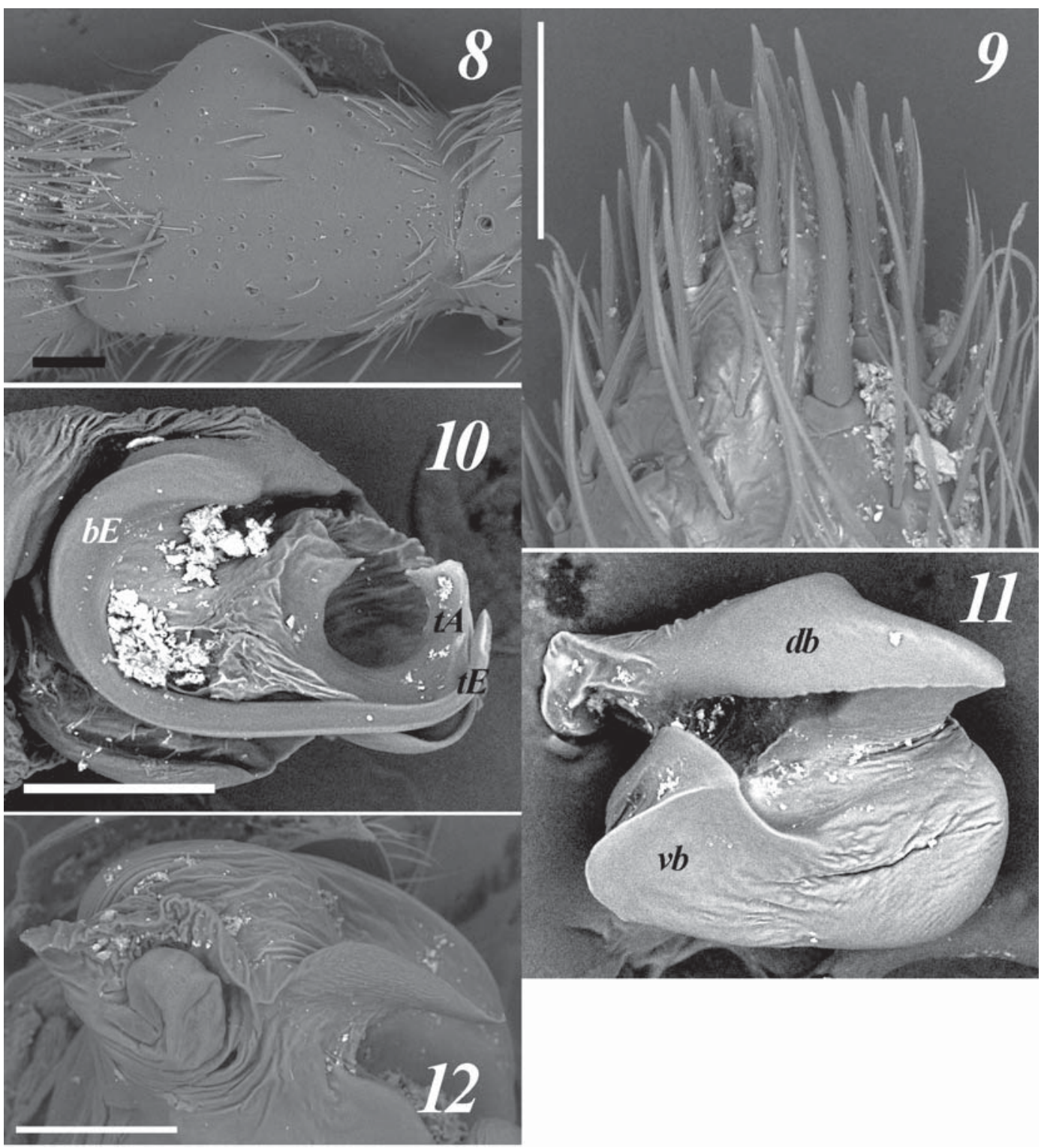

Figs 8-12. Details of male palp of Bogdocosa kronebergi (Andreeva, 1976): 8 - tibia, dorsal view; 9 - tip of cymbium with apical spines, ventral view; 10 - terminal part of bulbus, anterior view; 11 - tegular apophysis, ventral view; 12 - conductor, ventral view. Scale $0.1 \mathrm{~mm}$.

Abbreviations: $b E$ - base of embolus; $d b$ - dorsal branch of tegular apophysis; $t A$ - terminal apophysis; $t E$ — tip of embolus; $v b-$ ventral branch of tegular apophysis.

Рис. 8-12. Детали пальпа Bogdocosa kronebergi (Andreeva, 1976): 8 - голень, сверху; 9 - вершина цимбиума с апикальными щетинками; 10 - вершинная часть бульбуса, спереди; 11 - тегулярный отросток, снизу; 12 - кондуктор, снизу. Масштаб 0,1 мм.

Аббревиатура: $b E$ - основание эмболюса; $d b-$ дорсальная ветвь тегулярного отростка; $t A-$ терминальный отросток; $t E-$ вершина эмболюса; $v b$ - вентральная ветвь тегулярного отростка.

Tarentula andreevae Mikhailov, 1996: 108, an invalid emendation (not preoccupied by Tarentula cronebergi Thorell, 1875). Pardosa beijiangensis: Song et al., 1999: 329, Fig. 193H, N
$\left(\mathrm{O}^{\top}+\right)$.

Pardosa beijiangensis: Chen, Song, 2004: 406, Figs 1-9 ( $0^{7}+$ ).

Bogdocosa baskuntchakensis Ponomarev et Belosludtsev in Ponomarev et al., 2008: 164, Figs 1-6 ( $\left.\sigma^{7}+\right)$, syn.n.

Bogdocosa baskuntchakensis: Mirshamsi et al., 2015: 101, Figs 4-12 ( $\left.0^{7}+\right)$.

TYPES. Paratypes of Bogdocosa baskuntchakensis: $20^{7} 0^{7}$, 1 오 (CP: 25.23.1/1) from Russia, Astrakhan Province, BogdiskoBaskunchakskiy Reserve, Surikovskaya Ravine, 48 $09^{\prime} 24.17^{\prime \prime} \mathrm{N}$, $46^{\circ} 50^{\prime} 35.89^{\prime \prime} \mathrm{E}, 16-18$. VII.2002, E.A. Belosludtsev; 18 O $^{\top} 0^{7}, 1$ (CP: 25.23.1/2), same locality, $48^{\circ} 13^{\prime} 23.40^{\prime \prime} \mathrm{N}, 46^{\circ} 58^{\prime} 48.79^{\prime \prime} \mathrm{E}$, bank of lake, 7-10.VI.2005, E.A. Belosludtsev.

MATERIAL. Russia: 4 O $^{7}, 6$ 우 (CP: 25.23.1/3), Daghestan,

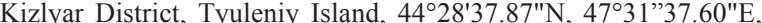
shrub (Tamarix) - Artemisia steppe, 11-14.VI.2009, S.V. Alieva \& N.Kh. Il'yasov; $13 \mathrm{O}^{7} \sigma^{7}, 7$ 우 (CP), Daghestan, Daghestan Nature Reserve, $44^{\circ} 42^{\prime} \mathrm{N}, 47^{\circ} 00^{\prime} \mathrm{E}$, Sarykum sand dune, 23.IV-4.VI. 2017, M.A. Aliev. Kazakhstan: 2 우 (PSU-6443), Zhambyl Region, Balkhash Lake, $46^{\circ} 53^{\prime} \mathrm{N}, 74^{\circ} 44^{\prime} \mathrm{E}, 2007$, K. Fadeev; $10^{\top}$ (ZMMU), West Kazakhstan Region, near Zhanybek Vil., 49 $23^{\prime} \mathrm{N}$, $46^{\circ} 48^{\prime} \mathrm{E}$, windbreak from Ulmus, pitfall-traps, 11-14.VI.1984, K.G. 
Table. Comparison of different populations of Bogdocosa kronebergi (Andreeva, 1976) according by somatic characteristics. Таблица. Сравнение различных популяций Bogdocosa kronebergi (Andreeva, 1976) по соматическим характеристикам.

\begin{tabular}{|c|c|c|c|c|}
\hline Region & Tadjikistan & Xinjiang Province & Astrakhan Area & Iran \\
\hline Publication & Andreeva, 1976 & Chen, Song, 2004 & $\begin{array}{l}\text { Ponomarev et al., } \\
2008\end{array}$ & $\begin{array}{l}\text { Mirshamsi et al., } \\
2015\end{array}$ \\
\hline Published name & $\begin{array}{l}\text { Alopecosa } \\
\text { kronebergi }\end{array}$ & $\begin{array}{l}\text { Pardosa } \\
\text { beijiangensis }\end{array}$ & $\begin{array}{l}\text { Bogdocosa } \\
\text { baskuntchakensis }\end{array}$ & $\begin{array}{l}\text { Bogdocosa } \\
\text { baskuntchakensis }\end{array}$ \\
\hline $\begin{array}{r}\text { Total length } \\
\text { male } \\
\text { female }\end{array}$ & $\begin{array}{l}4.9 \\
5.0\end{array}$ & $\begin{array}{c}4.4 \\
5.2-6.6\end{array}$ & $\begin{array}{c}5.7 \\
8.0-8.2\end{array}$ & $\begin{array}{l}5.7 \\
6.7\end{array}$ \\
\hline $\begin{array}{r}\text { Carapace lenght } \\
\text { male } \\
\text { female }\end{array}$ & $\begin{array}{l}2.5 \\
2.7\end{array}$ & $\begin{array}{c}2.5 \\
2.6-2.9\end{array}$ & $\begin{array}{c}2.8 \\
2.7-2.9\end{array}$ & $\begin{array}{l}3.1 \\
3.1\end{array}$ \\
\hline $\begin{array}{r}\text { Carapace width } \\
\text { male } \\
\text { female }\end{array}$ & - & $\begin{array}{c}1.8 \\
1.8-2.2\end{array}$ & $\begin{array}{c}2.1 \\
2.0-2.2\end{array}$ & $\begin{array}{l}2.2 \\
2.2\end{array}$ \\
\hline Carapace coloration & $\begin{array}{l}\text { Brown, with a } \\
\text { wide median light } \\
\text { stripe and } \\
\text { marginal light } \\
\text { bands }\end{array}$ & $\begin{array}{l}\text { Pale (probably } \\
\text { owing to } \\
\text { preservation in } \\
\text { alcohol), with a } \\
\text { wide median } \\
\text { yellow stripe and } \\
\text { marginal yellow- } \\
\text { white bands }\end{array}$ & $\begin{array}{l}\text { Brown, with a wide } \\
\text { median yellow stripe } \\
\text { and marginal yellow } \\
\text { bands }\end{array}$ & $\begin{array}{l}\text { Brown, with a wide } \\
\text { median light stripe } \\
\text { and marginal light } \\
\text { bands }\end{array}$ \\
\hline Sternum coloration & Yellow & Yellow & Yellow & Yellow \\
\hline Dorsum coloration & $\begin{array}{l}\text { Dark greyish } \\
\text { brown, with a } \\
\text { wide light median } \\
\text { stripe }\end{array}$ & $\begin{array}{l}\text { (?) with a wide } \\
\text { pale median stripe }\end{array}$ & $\begin{array}{l}\text { Dark grey, with a } \\
\text { wide yellow median } \\
\text { stripe }\end{array}$ & $\begin{array}{l}\text { Black, with a wide } \\
\text { yellow-brown } \\
\text { median stripe }\end{array}$ \\
\hline Venter coloration & Yellow & - & Yellow & Yellow/Grey \\
\hline Leg coloration & Yellow & Yellowish brown & Yellow & Yellow \\
\hline $\begin{array}{l}\text { Male femur I } \\
\text { coloration }\end{array}$ & Brown & - & Dark brown (Fig. 1) & Brown \\
\hline Chelicera coloration & Brown & - & Brown & Brown \\
\hline Palp coloration & $\begin{array}{l}\text { Brown, patella } \\
\text { slightly lighter }\end{array}$ & $\begin{array}{l}\text { Brown, patella } \\
\text { slightly pale }\end{array}$ & $\begin{array}{l}\text { From dark brown } \\
\text { (Fig. 2) to yellow } \\
\text { (Dagestan), patella } \\
\text { slightly lighter }\end{array}$ & - \\
\hline $\begin{array}{l}\text { Eyes of the anterior } \\
\text { row }\end{array}$ & $\begin{array}{l}\text { AME bigger than } \\
\text { ALE; } \\
\text { AME and ALE } \\
\text { contiguous }\end{array}$ & $\begin{array}{l}\text { AME bigger than } \\
\text { ALE; } \\
?\end{array}$ & $\begin{array}{l}\text { AME slightly bigger } \\
\text { than ALE; } \\
\text { MAE and ALE } \\
\text { contiguous }\end{array}$ & - \\
\hline
\end{tabular}

Mikhailov (as Pardosa xinjiangensis Hu et Wu, 1989; misidentification).

DIAGNOSIS. See above under the generic 'Diagnosis and Affinities'.

DESCRIPTION. See Chen, Song [2004: 406-407; sub Pardosa beijiangensis] and Ponomarev et al. [2008: 164].

NOTES. In Introduction (see above), we have mentioned that $B$. kronebergi has been described or reported from cis-Caspian Region and Central Asia under the four names: Tarentula latifasciata [Kroneberg, 1875: 90 only], Alopecosa kronebergi [Andreeva, 1976], Pardosa beijiangensis [Hu, Wu, 1989; Zhao, 1993; Song et al., 1999; Chen, Song, 2004] and Bogdocosa baskuntchakensis [Ponomarev et al., 2008; Mirshamsi et al., 2015]. The type specimens of three species names ( $T$. latifasciata, $A$. kronebergi and $P$. beijiangensis) have not been studied here, but there are detailed, recent and reliable (re)descriptions and figures of all the diagnostic characters of both males and females [Andreeva, 1976; Chen, Song, 2004; Ponomarev et al., 2008].

Three species populations of $B$. kronebergi, described as different species (viz., A. kronebergi, P. beijiangensis and $B$. baskuntchakensis) have the same somatic characteristics (see Table) and do not differ in the structure of the male palp and the epigyne (Fig. 14-17). The known localities of these species form a continuous range (Fig. 13). Therefore, it is safe to synonymize these three species names. 


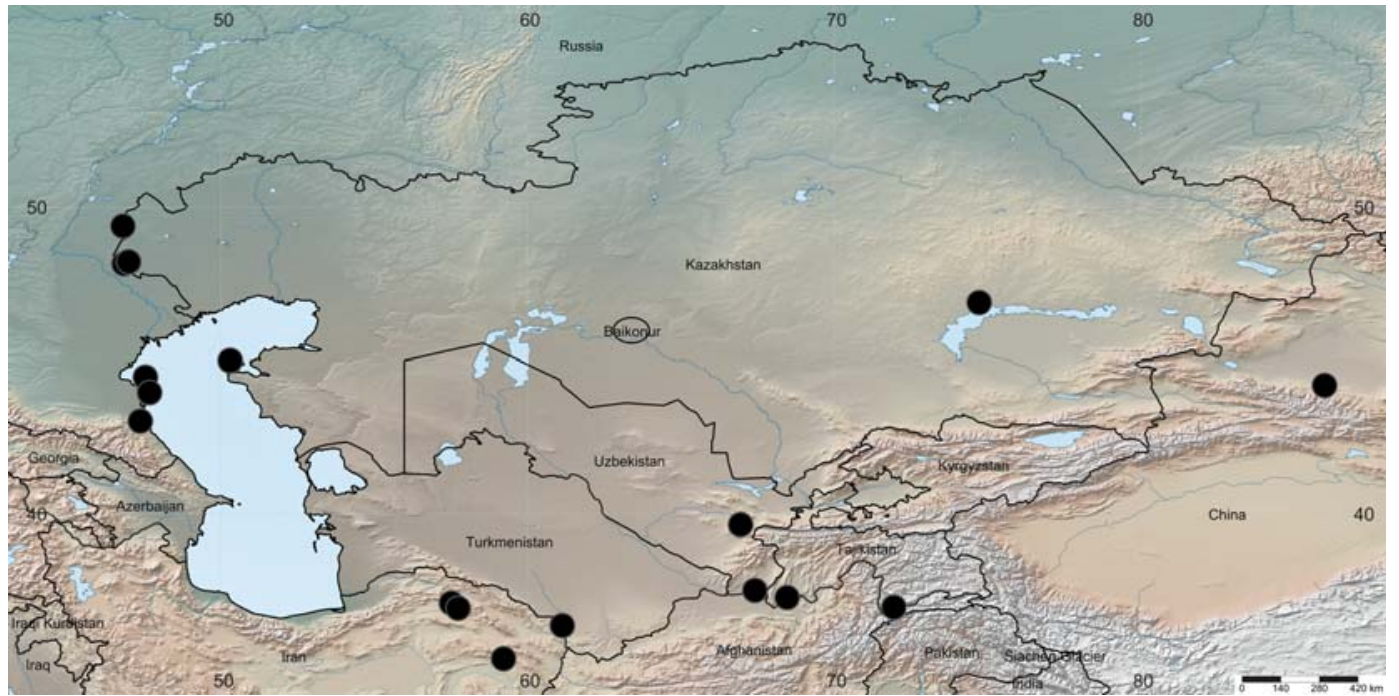

Fig. 13. Collecting localities of Bogdocosa kronebergi (Andreeva, 1976).

Рис. 13. Точки находок Bogdocosa kronebergi (Andreeva, 1976).
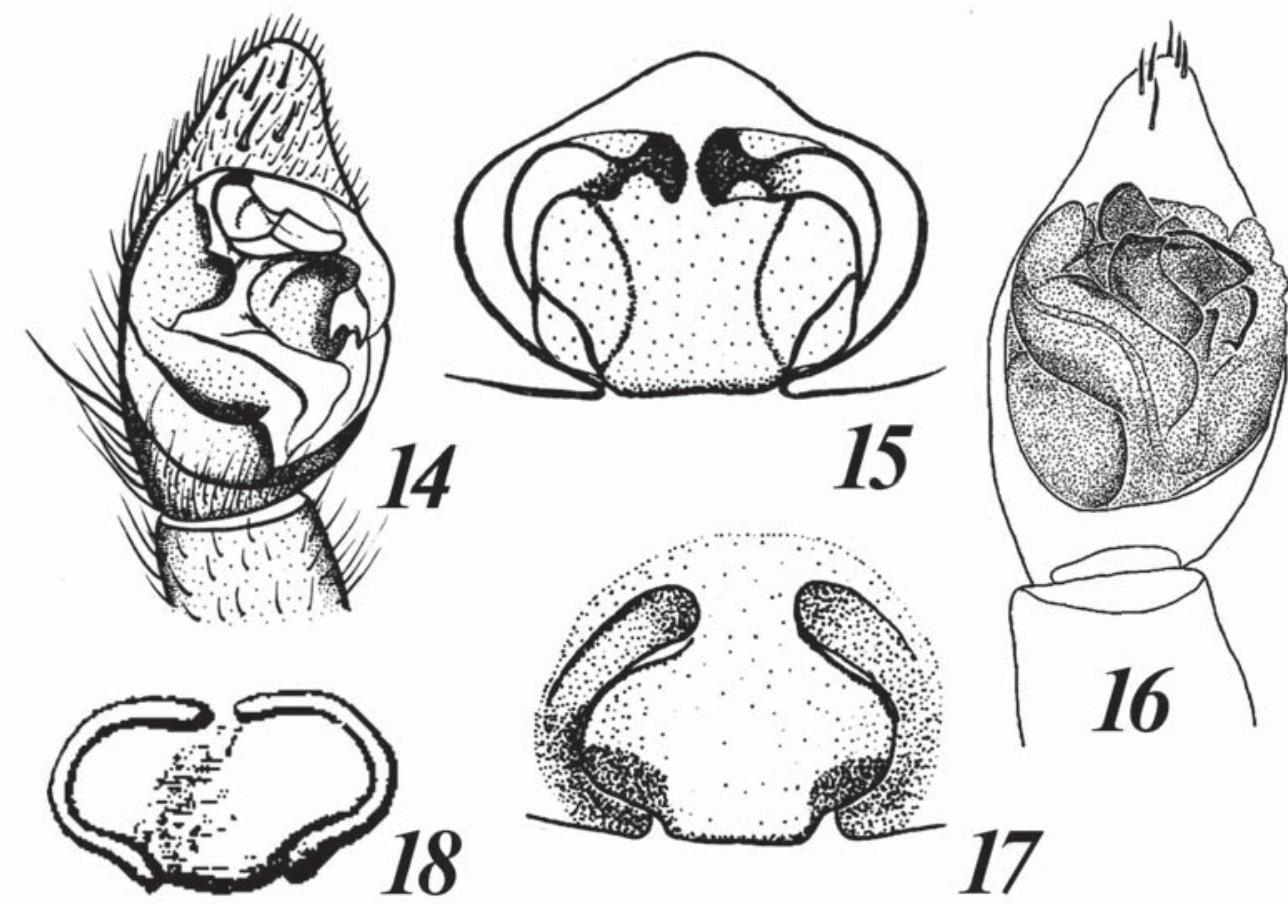

\section{7}

Figs 14-18. Variations of figures of palp (14, 16, ventral view) and epigyne $(15,17,18$, ventral view) of Bogdocosa kronebergi (Andreeva, 1976).

Figures are from the following publications: 14, 15 - after Andreeva [1976, figs 54-55, as Alopecosa kronebergi]; 16, 17 - after Song, Chen, 2004: figs 2, 4, as Pardosa beijiangensis], 18 - after Kroneberg [1875, fig. 27e, as Tarentula latifasciata]. 1976).

Рис. 14-18. Варианты изображения пальпа (14, 16, снизу) и эпигины $(15,17,18$, снизу) Bogdocosa kronebergi (Andreeva,

Рисунки заимствованы из следующих публикаций: 14, 15 - [Андреева, 1976, рис. 54-55, как Alopecosa kronebergi]; 16, 17 — [Song, Chen, 2004: figs 2, 4, как Pardosa beijiangensis Hu et Wu, 1989], 18 — [Кронеберг, 1875, рис. 27е, как Tarentula latifasciata].

The females of $T$. latifasciata were described in less detail; however, the somatic characters (the total length of 7.0-8.5; carapace and abdomen with a light wide median stripe; sternum and abdomen ventrally light greyish brown) are in agreement with and the structure of its epigyne (Fig. 18 ) is identical to that of $B$. kronebergi.
DISTRIBUTION (Fig. 13). Iran: Northern Khorasan Province, Chenar Sookhte Vil., 37 $07^{\circ} 21.17^{\prime \prime} \mathrm{N}, 57^{\circ} 31^{\prime}$ $30.36^{\prime \prime} \mathrm{E}$, Baba Hossein cemetery, 36 $55^{\prime} 34.84^{\prime \prime} \mathrm{N}, 57^{\circ} 44^{\prime}$ $07.35^{\prime \prime} \mathrm{E}$; Khorasan-e Razavi Province, Torbate Heydariyeh, $35^{\circ} 16^{\prime} 27.9^{\prime \prime} \mathrm{N}, 59^{\circ} 13^{\prime} 09.59^{\prime \prime} \mathrm{E}$, Dowlat Abad Village, $36^{\circ}$ $21^{\prime} 09.46^{\prime \prime} \mathrm{N}, 61^{\circ} 08^{\prime} 00.30^{\prime \prime} \mathrm{E}$ [Mirshamsi et al., 2015: as $B$. 
baskuntchakensis]. Russia: Astrakhan Region: BogdiskoBaskunchakskiy Reserve [Ponomarev et al., 2008: as $B$. baskuntchakensis]; Daghestan Republic: nr. Makhachkala Town, $43^{\circ} 02^{\prime} \mathrm{N}, 47^{\circ} 22^{\prime} \mathrm{E}$, Chechen' Island in Caspian Sea, $43^{\circ} 58^{\prime} \mathrm{N}, 47^{\circ} 40^{\prime} \mathrm{E}$; Kizlyar Distr.: Tyuleniy Island [Ponomarev et al., 2011; Abdurakhmanov et al., 2012: as B. baskuntchakensis; Ponomarev, Abdurakhmanov, 2014: as B. baskuntchakensis] and Dagestan Nature Reserve, $44^{\circ} 42^{\prime} \mathrm{N}$, $47^{\circ} 00^{\prime} \mathrm{E}$ [present data]. Kazakhstan: West Kazakhstan Region [Piterkina, Mikhailov, 2009: as P. xinjiangensis], Mangistau (=Mangyshlak) Area, Kulaly Island in Caspian Sea, $45^{\circ} 00^{\prime} \mathrm{N}, 50^{\circ} 18^{\prime} \mathrm{E}$ [Ponomarev, Abdurakhmanov, 2014: as B. baskuntchakensis], Zhambyl Area: Balkhash Lake [present data]. Uzbekistan: Samarkand, $39^{\circ} 39^{\prime} \mathrm{N}, 66^{\circ} 57^{\prime} \mathrm{E}$ [Kroneberg, 1875: as T. latifasciata non Kroneberg, 1875]; ?Larkurgan, $37^{\circ} 30^{\prime} \mathrm{N}, 67^{\circ} 25^{\prime} \mathrm{E}$ [Andreeva, 1976: as juvenile specimens A. kronebergi]. Tajikistan: Khatlon Region, Tigrovaya Balka Nature Reserve, $37^{\circ} 16^{\prime} \mathrm{N}, 68^{\circ} 28^{\prime} \mathrm{E}$; GornoBadakhshan Autonomous Region, Ishkashim District, DarayAbkharv Canon, $36^{\circ} 57^{\prime} \mathrm{N}, 71^{\circ} 57^{\prime} \mathrm{E}$ [Andreeva, 1976: as $A$. kronebergi]. China: Xinjiang Uyghur Autonomous Region, Shihezi City, $44^{\circ} 12^{\prime} \mathrm{N}, 86^{\circ} 00^{\prime} \mathrm{E}$ [Hu, Wu, 1989: as P. beijiangensis; Song et al., 1999: as P. beijiangensis; Chen, Song, 2004: as $P$. beijiangensis].

Acknowledgements. We wish to express our gratitude to the following persons for giving access to the studied material: E.A. Belosludtsev (Samara, Russia), G.M. Abdurakhmanov \& S.V. Alieva (Makhachkala, Russia), T.K. Tuneva (Ekaterinburg, Russia). We are indebted to K.G. Mikhailov (ZMMU) for giving access to the material from the collection of the Zoological Museum of the Moscow State University. We are also obliged to V.Yu. Shmatko (Southern Scientific Centre of RAS, Rostov-on-Don) and A.V. Grischenko (Zoological Museum of the Perm State University, Perm) for producing digital photographs and SEM micrographs, respectively. Special thanks go to D.V. Logunov (Manchester, UK) for commenting on the manuscript and for editing the English of the final draft. The research programme by the second author (AP) was supported by the government contract for the Southern Scientific Centre of RAS, project 01201363191.

\section{References}

Abdurakhmanov G.M., Ponomarev A.V., Alieva S.V. 2012. [Spiders (Arachnida: Aranei) in Dagestan Republic: species composition, distribution]. Makhachkala: Dagestan University Press. 220 p. [in Russian]

Andreeva E.M. 1976. [Spiders of Tajikistan. The fauna and zonalecological distribution]. Dushanbe: Donish. 193 p. [in Russian]

Charitonov D.E. 1946. [New forms of spiders of the USSR] // Izvestija Estestvenno-Nauchnogo Instituta pri Molotovskom Gosudarstvennom Universitete. Vol.12. P.19-32 [in Russian].

Charitonov D.E. 1969. [Materials to spider fauna of USSR] // Uchenye Zapiski, Permskij Gosudarstvennyi Universitet. No.179. P.59-133 [in Russian].

Chen J., Song D.X. 2004. A taxonomic study on the spiders of Pardosa multivaga group (Araneae: Lycosidae) // Oriental Insects. Vol.38. P.405-417.

Hu J.L. 2001. [Spiders in Qinghai-Tibet Plateau of China]. Henan: Henan Science and Technology Publishing House. 658 p. [in Chinese]

Hu J.L., Wu W.G. 1989. [Spiders from agricultural regions of Xinjiang Uygur Autonomous Region, China]. Jinan: Shandong University Publishing House. 435 p. [in Chinese]

Kroneberg A. 1875. [A.P. Fedtchenko. Voyage in Turkestan. Spiders. Araneae] // Izvestiya Obshchestva lyubitelei estestvoz- naniya, antropologii i etnografii. Vol.19. No.3. P.1-55 [in Russian]

Marusik Yu.M., Kovblyuk M.M., Koponen S. 2011. A survey of the east Palaearctic Lycosidae (Araneae). 9. Genus Xerolycosa Dahl, 1908 (Evippinae) // ZooKeys. Vol.119. P.11-27.

Mikhailov K.G. 1996. A checklist of the spiders of Russia and other territories of the former USSR // Arthropoda Selecta. Vol.5. No.1/2. P.75-137.

Mirshamsi O., Saneei S., Aliabadian M., Ghassemzadeh F. 2015. New data on the wolf spides of Iran (Aranei: Lycosidae) // Arthropoda Selecta. Vol.24. No.1. P.99-106.

Piterkina T.V., Mikhailov K.G. 2009. [Annotated list of spiders (Aranei) of the Dzhanybek station] // Zhivotnye glinistoi polupustyni Zavolzh'ya (konspekty faun i ekologicheskie kharakteristiki). Moscow: KMK Scientific Press. P.62-88 [in Russian].

Ponomarev A.V., Abdurakhmanov G.M. 2014. [Spiders (Aranei) of northern Caspian Sea coast and islands] // Yugh Rossii: ekologiya, razvitie. No.1. P.76-121 [in Russian].

Ponomarev A.V., Abdurakhmanov G.M., Alieva G.M., Dvadnenko K.V. 2011. [Spiders (Arachnida: Aranei) of the coastal and insular territories of the North Dagestan] // Yugh Rossii: ekologiya, razvitie. No.4. P.126-143 [in Russian].

Ponomarev A.V., Belosludtsev E.A., Dvadnenko K.V. 2008. [Spiders (Aranei) of the lower Volga region (Astrakhan and Volgograd Areas of Russia) with the description of new taxa] // Caucasian Entomological Bulletin. Vol.4. No.2. P.163-185 [in Russian].

Qiu Q.H., Wang X.P. 1992. [The lycosid species in the Yellow River valley of Shanxi, Henan and Shaanxi (Araneae: Lycosidae)] // Acta Zootaxonomica Sinica. Vol.17. No.1. P.2628 [in Chinese].

Russell-Smith A. 1981. A revision of the genus Chaleposa Simon (Araneae: Lycosidae) // Journal of Natural History. Vol.15. P.223-244.

Russell-Smith A. 1982. A revision of the genus Trabaea Simon (Araneae: Lycosidae) // Zoological Journal of the Linnean Society. Vol.74. P.69-91.

Shorthouse David P. 2010. SimpleMappr, an online tool to produce publication-quality point maps. Available at http://www. simplemappr.net (accessed August 12, 2017).

Simon E. 1880. Etudes arachnologiques. 11e Mémoire. XVII. Arachnides recueilles aux environs de Pékin par M. V. Collin de Plancy // Annales de la Société Entomologique de France. 5 Série. Vol.10. P.97-128.

Snazell R. 1983. A new wolf spider of the genus Trabaea (Araneae: Lycosidae) from southern Spain // Bulletin of the British Arachnological Society. Vol.6. Pt.2. P.75-77.

Song D.X. 1987. [Spiders from agricultural regions of China (Arachnida: Araneae)]. Beijing: Agriculture Publishing House. 376 p. [in Chinese]

Song D.X., Huber M. 1983. [A redescription of the spiders of Beijing described by E. Simon in 1880] // Journal of the Huizhou Teachers College. No.2. P.1-23 [in Chinese].

Song D.X., Zhu M.S., Chen J. 1999. The Spiders of China. Shijiazhuang: Hebei University of Science and Techology Publishing House. $640 \mathrm{p}$

Song D.X., Zhu M.S., Chen J. 2001. [The Fauna of Hebei, China: Araneae]. Shijiazhuang: Hebei University of Science and Techology Publishing House. 510 p. [in Chinese]

Yin C.M., Peng X.J., Xie L.P., Bao Y.H., Wang J.F. 1997. [Lycosids in China (Arachnida: Araneae)]. Hunan: Hunan Normal University Press. 317 p. [in Chinese]

Zhang W.S. 1987. [Farm spiders from Hebei Province]. Hebei: Hebei University of Science and Techology Press. 299 p. [in Chinese]

Zhao J.Z. 1993. [Spiders in the Cotton Fields in China]. Wuhan: Wuhan Publishing House. 552 p. [in Chinese]

Zyuzin A.A. 1985. [Generic and subfamilial criteria in the systematics of the spider family Lycosidae (Aranei), with the description of a new genus and two new subfamilies] // Trudy Zoologicheskogo Instituta AN SSSR. Vol.139. P.40-51 [in Russian]. 